Rafał Bilski

\title{
THE POWER RATIO OF BANDS OF LOW AND HIGH FREQUENCY IN NORMALIZED UNITS IN THE FFT METHOD AS A MARKER FOR QUANTITATIVE ASSESSMENT OF THE EFFECTIVENESS OF HRV BIOFEEDBACK SESSION
}

\author{
OCENA SKUTECZNOŚCI SESJI BIOFEEDBACKU HRV \\ ZA POMOCĄ STOSUNKU MOCY PASM NISKICH I WYSOKICH CZESTOTLIWOŚCI, \\ WYRAŻONYCH W JEDNOSTKACH ZNORMALIZOWANYCH
}

Department of Ecology and Enviromental Protection CM UMK

S u m m a r y

HRV biofeedback is an effective method of relaxation and the fight against certain diseases. The effect exerted on the body has been documented many times. The main problem turned out to be a quantitative assessment of the effectiveness of the session. Among many characteristics which describe the variability of the heart rate, the power ratio of the high and low bands in units of normalized frequency obtained by the method of $\mathrm{FFT}(\mathrm{LF} / \mathrm{HF})$ were selected to the survey.

The aim of this study was to examine whether power ratio of bands of low and high frequency in normalized units obtained by the FFT methods is suitable for the quantitative description of the effectiveness of biofeedback session hrv .
The study group consisted of 30 healthy people aged 21-25 years without any experience of the analyzed phenomenon. The study used a non-invasive method of measuring the blood flow through the ear of the participant, then the software program described it quantitatively.

It turned out that the LF/HF cannot be used for quantitative evaluation of HRV BF session without further tests, but it is advisable to carry out long-term studies with the larger population of people. A surprising result was the observation of study participants, in short stage of relaxation, before the proper part of the study. Subjects knowing that soon they will participate in the active session mentally prepared themselves on the regulation of the breath which is confirmed by the results.

\section{Streszczenie}

Biofeedback HRV to skuteczna metoda relaksacji oraz walki z niektórymi chorobami. Efekt wywierany na organizm został już wiele razy udokumentowany. Zasadniczym problemem okazała się ilościowa ocena skuteczności sesji. Spośród wielu parametrów mogących opisać zmienność rytmu serca do badania wybrana została moc stosunku pasm niskich i wysokich częstotliwości w jednostkach znormalizowanych w metodzie FFT(LF/HF).

Celem niniejszej pracy było sprawdzenie, czy moc stosunku pasm niskich i wysokich częstotliwości w jednostkach znormalizowanych $\mathrm{w}$ metodzie FFT nadaje się do opisu ilościowego skuteczności sesji biofeedbacku HRV.
Badaniami objęto grupę 30 zdrowych osób w wieku 21-25 lat bez jakiegokolwiek doświadczenia $\mathrm{z}$ analizowanym zjawiskiem. Do badań wykorzystano nieinwazyjne metody pomiaru przepływu krwi przez ucho uczestnika, następnie z pomocą odpowiedniego oprogramowania opisano ilościowo wyniki.

Okazało się, iż moc stosunku pasm niskich i wysokich częstotliwości w jednostkach znormalizowanych w metodzie FFT nie może być wykorzystywana do oceny ilościowej sesji BF HRV, bez przeprowadzenia badań długoterminowych na większej populacji uczestników. Zaskakującym efektem badań okazała się obserwacja uczestników w krótkim etapie 
poprzedzającym właściwą część badań. Osoby badane, wiedząc że za chwilę przystąpią do właściwej sesji, psychicz-

Key words: quality of life, University of the Third Age, old age

Stowa kluczowe: jakość życia, Uniwersytet Trzeciego Wieku, wiek podeszły

\section{INTRODUCTION}

\section{Biofeedback}

The concept of biofeedback derived from two words, biological and feedback. This technique is used to self-conscious functions of the body that are considered to be independent of the will and consciousness. Changes that occur within the system are monitored by the measuring device, converted by a computer program and then passed as feedback for the participant surveys, showing the work of the body $[1,2]$. During BF session, participant can see the impact of their behaviour on physiological functions, which in the long term can be controlled. There are different types of biofeedback, using the heart rate, brain waves, electrical resistance of the skin or muscle tension $[3,4]$.

\section{HRV Biofeedback}

In this study type of biofeedback techniques based on the phenomenon of the heart rate variability was used. It is a natural phenomenon reflecting changes in heart rate. This method uses a feedback connection between the work of the heart and autonomic nervous system [5]. The purpose of this type of feedback is the synchronization of the respiratory system, in which the functioning of subjects affected with cardiovascular work translates into getting the desired psychophysiological state [6]. This technique is largely based on the phenomenon of respiratory sinus arrhythmia, resulting in a significant increase in heart rate during inspiration and a decrease during exhalation [7, 8]. ANS Monitoring involves comparing this two values. For breath in a significantly greater extent corresponds to the sympathetic nervous system, while the exhaust is the domain of the parasympathetic system. As a result of mental calm, slow down and adjust the breath can consciously increase the regularity of the heart. The measuring device transmits the read frequency of the contractions of the heart to the computer, where it is converted to feedback information understandable to the tested person. These signals are usually displayed on a monitor in the form of graphic or sound coming from the headphone. As a result, patients can freely change the way they breathe nie nastawiały się na regulację oddechu, co potwierdzają wyniki.

or the mental attitude, observing how it affects the work of the heart [9].

\section{Psychophysiological coherence}

In the human body there is a number of organs controlled by the central nervous system, which sends daily tons of pulses allowing maintaining a proper rhythm of work of all systems. Referring to determining the physiological coherence, we talk about the degree of order and stability of waves symbolizing compensated activity of one of the systems within a specified period of time [10]. Coherence is a physiological condition which increases balance and mutual activity of various systems that oscillate between each other [11]. This condition is associated with a shift of autonomic balance towards increased activity of the parasympathetic system and the interplay of individual organ systems. Physiological Coherence is a natural state for the body, which could occur spontaneously, usually within a short period of time. There are ways to allow maintenance of this state by means of rhythmic breathing. Studies have shown that positive and negative emotions have impact on the state of physiological coherence. Stress, anxiety, anger lead to disorders, while positive feelings intensify and prolong the natural physiological coherence [12]. There have been proposed methods to somehow control the functioning of the body by inducing the appropriate emotional impulses. This condition, associated with positive emotions which characterize a high degree of emotional awareness and control of the changes made, is called psychophysiological coherence. Ability to maintain positive emotions entails a number of consequences, among which can be distinguished better cognitive functioning, increase the capacity involving creativity and intuition. The consequence of maintaining the state of psychophysiological coherence is the relaxation. The ways to impose this condition in life may include a prayer, a meditation, and among modern methods, the technique of biofeedback $[13,14]$ 


\section{LF/HF}

The power ratio of the high and low band frequencies in standard units FFT method is the parameter belonging to the frequency domain indices expressed in standard units, and obtained by rapid Fourier transformation. Described variable is the ratio of the power spectra of the low to high-frequency part of the total HRV spectrum [15]. This parameter reflects the cooperation of sympathetic and vagal nerve stimulation. Drawdown can attest to the increased proportion of high-frequency spectral analysis of HRV in total and hence an increase in tension, psychophysiological stress, and a feeling of readiness for action. As this type of variable that is correlated to the operation of the vagus nerve is decreased, values may indicate a pathology construction of the heart, hypertension, increased risk of atherosclerosis and diabetes. [16] Also, the values that are below the standard are characteristic for overweight and obesity. [17]

\section{AIM OF THE STUDY}

The aim of this study was to examine whether relative power bands of low and high frequency in normalized units in the FFT method are suitable for quantitative description of the effectiveness of HRV biofeedback session.

\section{MATERIAL AND METHODS}

\section{Participants}

In this study took part 30 healthy people (26 women and 4 men), aged 21-25 years. Participants were students with no prior experience in the HRV biofeedback techniques. Subjects were divided into 6 random groups of different sizes, each of which has been subjected to identical HRV biofeedback sessions. Within six weeks there were 12 measurements of heart rate variability. Each week the break between measurements was a three days period. Each person participating in the study was assigned to one of six computer stations equipped with chair, table, laptop, headphones, and assumed the measuring device on the ear lobe. Before performing the measurement study group was trained with the operation of the software emWave Desktop PC, the task of which was to note the heart rate of the participants. The students task was to launch the audio application, containing instructions for executed exercise, and measurement program.

\section{HRV measurement}

The device from HeartMathwas used for measurement, emWave, was supported by the emWave Desktop software. The instrument that measures the heart rate variability, is equipped with a USB module with plethysmographic sensor and placed on the subject's ear lobe. The machine recorded the changes in peripheral blood flow through the blood vessels close to the skin surface. Used software gave participants the ability to master the techniques of obtaining the high psychophysiological coherence state. The subject received the graphical feedback on a computer screen. It was given by the heart rate in real time as well as indicators of the level of coherence. The user, on the basis of the data obtained, can modify the heart through changes in their behaviour (the most important role of breathing). Appropriate adjustment of the length and frequency of the performed inhalations and exhalations can stabilize heart rhythm on an equal level, increasing the values of HRV and coherence. Each participant took part in 12 sessions over 6 weeks. Each session was divided into two phases, a short fiveminute relaxation area and a 15 minute during which participants performed the commands contained in the soundtrack.

\section{Collecting data}

Results of this study were collected on a computer disk. Each measurement was recorded as a .xml file and saved in the folder consisting of the data set for further processing in accordance with the adopted coding system. These files were converted to the format txt using prepared script in MS Excel 2007. Thus, prepared files can be read by Kubios HRV 2.0, allowing statistical analysis and nonlinear spectral data obtained. This software is a valuable feature that allows you to analyse not only the entire tachogram, but also arbitrarily selected fragments. In this way you can separate the analysis of the short 5 minute episode relaxation from the 15 minute part of the active biofeedback. The results are summarized in MS Excel 2007.

\section{STATISTICAL ANALYSIS}

In the statistical analysis two techniques for qualification data were used: factor analysis and student t-test for dependent variables. Factor analysis is a method used for study the internal structure based on multi-dimensional observation. Each variable is an 
observable presentation as a linear combination of a number of unobserved variables called factors. Factors are common to the entire set of input variables and one non-observable factor specific for this variable, the common and specific factors are not correlated. The primary objective of this approach was to identify the independent variables among those obtained in the Kubios HRV. The calculations performed in this work was used varimax normalized rotation. This procedure consisted of reducing the number of variables having high values for each of the factors. The result of the rotation was carried out to obtain the eigenvalues for each of the factors. These values represent how many times more specific factors explain variance in relation to the variation of one parameter. The largest part of the variance explained factor number one, and the next explain these have not been explained by previous factors. According to the Kaiser criterion for further interpretation were eligible only those factors whose eigenvalue was greater than or equal to 1 student T-test for dependent variables was used instead to determine the statistical significance of the results. In this case, the limit value was $p \leq 0.05$. Each week study was subjected to the above statistical procedure.

\section{RESULTS}

During the performed measurements various parameters were compared. Some of them proved to be very good markers for BF session quantitative description HRV. On the following figures the average value of LF/HF of all 30 participants, on each week study, is shown. The broken line shows graphically the result of T-test component of the statistical analysis. In figures a trend line and the standard deviation in consecutive intervals were also shown.

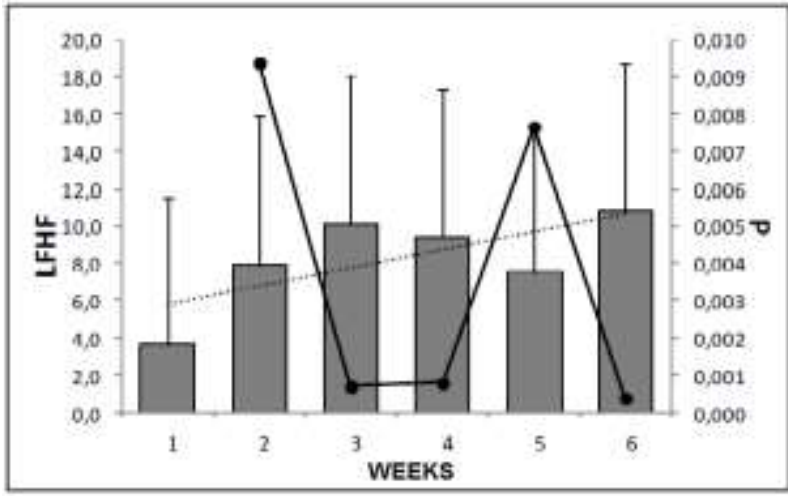

Fig. 1. Changes in LF / HF within 6 weeks of research during the relaxation part of study
In the course of parameter changes of $\mathrm{LF} / \mathrm{HF}$ at rest, immediately preceding the appropriate biofeedback HRV sessions, the marker has a high statistical significance, tested by T-test, in all tests weeks $(p<0.05)$. The lowest value of the described variable was reached in the first week. During the subsequent time intervals there was a slow growth in the values. The exception to this observation was the fourth and the fifth week, in which you can see a slight decrease in value. In the sixth and final time interval, a growing trend returned. Comparing the first and the last week of the research a clear difference in the LFHF can be observed.

The fluctuations of the level of the $\mathrm{LF} / \mathrm{HF}, \mathrm{BF}$ during the active session HRV, over six weeks the measurements for almost the entire study period parameter maintained at a high level of statistical significance $(\mathrm{p}<0.05)$. The exception was the fourth week, where a small degree limit value was exceeded. During the first week $\mathrm{p}$ parameter was significantly lower than in the other ones. During the period from $\mathrm{T} 2$ to $\mathrm{T} 3$ variable was characterized by a growing trend. In T4, with a sudden drop in the value and then down to the last seven-day period draw up its growth.

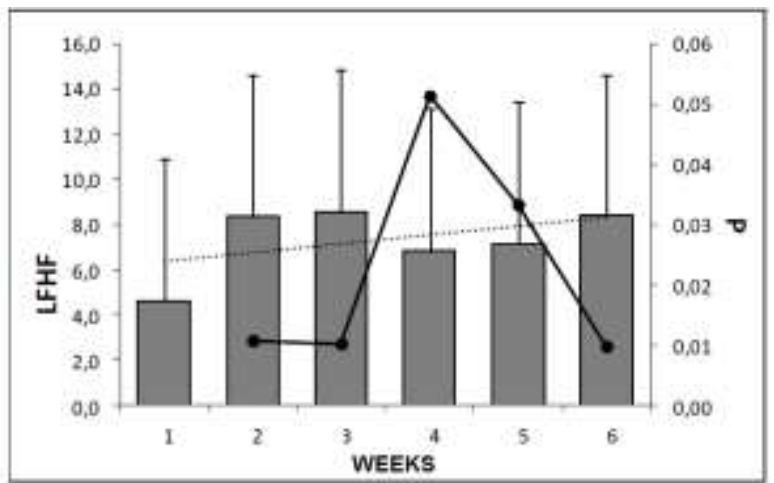

Fig. 2. Change the value of $L F / H F$ within 6 weeks of research during active part of study

\section{DISCUSSION}

The aim of the study was to determine whether LFHF is a good marker of the quantitative effect of HRV biofeedback session. In the context of HRV changes in the value of this parameter $\mathrm{LF} / \mathrm{HF}$ ratio reflects the mutual relationship and the balance of the two components of the ANS and expresses the interdependence of these two types of modulation [18, 19]. The fact that it is a good indicator of the functioning relative to each other and to stimulate the sympathetic nerve erroneous has been also proven. In 
new-borns, this parameter was used for an overall assessment of the autonomic nervous system arousal during sleep and in the course of dealing with them, the results showed that during sleep the activity of the respondents was significantly lower [20]. This was confirmed by the studies. The changes were seen during the session of biofeedback and indicates its proper course. Nevertheless, the lack of regularity in each week changes may be caused by an external stressor for a test group. In theory, a well-tested parameter reflects changes in the autonomic nervous system in correlation with the rhythm of the heart [21]. First week shows lower values of LF/HF as research participants have participated in an attempt to obtain informed feedback within the body for the first time (Fig. 2). Further intervals show an increase in value, which reduced the high-frequency part of the spectrum or the increase in the share of low frequency in the overall analysis. In the resting state; however, you can see the similarity graph structure to its counterpart showing changes in the LF/HF during the active session BF HRV. This shows that subjects regulated heart rhythm even before they heard the lector instructions, subconsciously preparing for the active session, and it is also a measure of the effect of the session which was maintained over time. This points to the fact that the research participants, sitting down in front of computer, were mentally prepared for the initiating in a few minutes HRV BF session. Prior to the commencement of the rhythm of respondents began to regulate, and week to week, this effect was becoming more and more deepened.

\section{CONCLUSIONS}

1. The study did not show clearly whether LFHF is a good marker for quantitative assessment of the effectiveness of biofeedback session, heart rate variability, it is advisable to conduct studies involving longer duration of the project with a larger group test.

2. It turned out to be surprising that changes in the start of HRV before launch of the active session.

\section{REFERENCES}

1. Kemp A.H., Quintana D.S., Gray M.A., Felmingham K.L., Brown K., Gatt J.M., Impact of Depression and Antidepressant Treatment on Heart Rate Variability: A Review and Meta-Analysis, Biological Psychiatry, 67:1067-1074, 2010.
2. Schwartz MS, Andrasik F. Biofeedback: a practitioner's guide. New York: Guilford Press, 2003.

3. Moss D. Mind/body medicine, evidence-based medicine clinical psychophysiology, and integrative medicine. : Moss D, McGrady A, Davies T, et al., editors. (eds)Handbook of Mind Body Medicine in Primary Care: behavioral and physiological tools. Thousand Oaks: Sage, 2003, pp. 3-18.

4. Frank D.L., Khorshid L., Kiffer J.F., Moravec C.S., McKee M.G., Biofeedback in medicine: who, when, why and how?, Mental Health in Family Medicine, 7:85-91, 2010.

5. McCraty R., Tomasino D., Heart Rhythm Coherence Feedback: A New Tool for Stress Reduction, Rehabilitation, and Performance Enhancement, HeartMath Research Center, Institute of HeartMath, Boulder Creek, California, USA, 2004.

6. Edwards, S. D. Evaluation of heart rhythm coherence feedback training on physiological and psychological variables, South African Journal of Psychology 2014, Vol. 44(1) 73-82

7. Mikosch $\mathrm{P}^{1}$, Hadrawa T, Laubreiter K, Brandl J, Pilz J, Stettner H, Grimm G Effectiveness of respiratorysinus-arrhythmia biofeedback on state-anxiety in patients undergoing coronary angiography. J. Adv. Nurs., 66(5):1101-1110 2010.

8. Edwards, S. D. (2013). Influence of a breath-based, selfidentification meditation on identity, mindfulness and spirituality perceptions. Journal of Psychology in Africa, 23, 69-76.

9. Adrian Meule Rebecca Freund Ann Kathrin Skirde Claus Voegele Andrea Kuebler Heart Rate Variability Biofeedback Reduces Food Cravingsin High Food Cravers Appl Psychophysiol Biofeedback, 37:241-251. 2012.

10. Fredrickson, B. L. What good are positive emotions? Review of General Psychology, 2: 1998

11. Klepp, O. M., Mastekaasa, A., Sorensen, T., Sandanger, I., \& Kleiner, R. Structure analysis of Antonovsky's sense of coherence from an epidemiological mental health survey with a brief nine-item sense of Coherence Scale. International Journal of Methods in Psychiatric Research, 16, 11-22., 2007

12. Fredrickson B. L. Positive emotions, Handbook of positive psychology. Oxford University Press., 2002

13. Fredrickson, B. L., Branigan, C. Positive emotions broaden the scope of attention and thought-action repertoires. Cognition and Emotion, 19, 2008

14. Isen, A. M. Positive affect. Handbook of cognition and emotion, 20:522-539, 1999

15. Tarvainen M. P. and Niskanen J. P. Kubios HRV. Users Guide 2.0. Kuopio. Biosignal Analysis and Medical Imaging Group, Department of Physics, University of Kuopio, 2008.

16. Freeman R, Saul JP, Roberts MS, Berger RD, Broadbridge $\mathrm{C}$, CohenRJ. Spectral analysis of heart rate in diabeticautonomic neuropathy. A comparison with standard tests of autonomic function. Arch Neurol 48:185-190, 1991. 
17. Task Force of the European Society of Cardiology, North AmericanSociety of Pacing Electrophysiology. Heart rate variability: standards ofmeasurement, physiological interpretation, and clinical use. Circulation93: 10431065, 1996.

18. Malik, M. Heart rate variability: Standards of measurement, physiological interpretation, and clinical use. Task Force of the European Society of Cardiology and the North American Society of Pacing and Electrophysiology. Eur. Heart J., 17, 354-381, 1996.

19. Malliani A, Lombardi F, Pagani M. Power spectral analysis of heart rate variability: a tool to explore neural regulatory mechanisms. Br Heart J 1994; 71: 1-2.

20. Smith S.L., Haley S., Slater H., Moyer-Mileur L.J. Heart rate variability during caregiving and sleep after massage therapy in preterm infants EarlyHuman Development 89: 525-529 2013.

21. Chen X., Mukkamala R., Selective quantification of the cardiac sympathetic and parasympathetic, American Journal Physiology. Heart and Circulatory Physiology 294: H362-H371, 2008.
Address for correspondence:

Department of Ecology

and Enviromental Protection

UMK w Toruniu

Collegium Medicum w Bydgoszczy

ul. M. Curie Skłodowskiej

85-094 Bydgoszcz

Received: 27.08.2014

Accepted for publication: 17.11.2014 